\title{
Variation in Seed-Quality Traits of Chickpea and Their Correlation to Raffinose Family Oligosaccharides Concentrations
}

\author{
Runfeng Wang, Manu P. Gangola, Sarita Jaiswal, Monica Båga, \\ Pooran M. Gaur, and Ravindra N. Chibbar*
}

\begin{abstract}
Genetic resources with desired seed composition are needed to improve nutritional quality of chickpea (Cicer arietinum L.) seeds. A germplasm collection of 171 chickpea genotypes (desi and kabuli types) was characterized for selected seed quality traits (thousand-seed weight [TSW], starch, protein, and amylose) in one greenhouse and two field trials. Kabuli-type chickpea genotypes (115.7 to $537.4 \mathrm{~g}$ and 36.2 to 49.0\%) had higher TSW and starch concentrations than desi types (114.6 to $332.4 \mathrm{~g}$ and 32.4 to $42.9 \%$ ), respectively. Desi type chickpea genotypes (16.7 to $27.5 \%$ ) showed a higher range for protein concentration than kabuli types (17.1 to $24.8 \%$ ). However, amylose concentration did not vary significantly between desi (29.7 to $34.4 \%)$ and kabuli (29.2 to $35.0 \%$ ) type chickpea genotypes. Genotype, environment, and their interaction showed a significant impact on selected seed-quality traits. Among the chickpea seedquality traits studied, seed weight was the most heritable trait, and it showed significant positive correlation with starch concentration. Protein, amylose, and total raffinose family oligosaccharides (RFO) had significant negative correlation with TSW. However, total RFO concentration showed significant positive correlation to both starch and protein concentrations. The identified desi and kabuli genotypes can be used as new genetic resources in chickpea improvement programs to develop chickpea varieties with enhanced nutritional composition.
\end{abstract}

R. Wang, M.P. Gangola, S. Jaiswal, M. Båga, and R.N. Chibbar, Dep. of Plant Sciences, College of Agriculture and Bioresources, Univ. of Saskatchewan, Saskatoon, SK S7N 5A8, Canada; P.M. Gaur, International Crops Research Institute for the Semi-Arid Tropics (ICRISAT), Patancheru, Hyderabad 502 324, Telangana, India. RW and MPG contributed equally to this work. Received 26 Aug. 2016. Accepted 12 Jan. 2017. ^Corresponding author (ravi.chibbar@usask.ca). Assigned to Associate Editor Candice Hirsch.

Abbreviations: E, environment; F 2009, field experiment done in 2008-2009; F 2010, field experiment done in 2009-2010; G, genotype; G 2010, greenhouse experiment done in 2010; $\mathrm{G} \times \mathrm{E}$, genotype $\times$ environment interaction; $H^{2}$, broad sense heritability; RFO, raffinose family oligosaccharides; SDI, Shannon-Weaver diversity index; TSW, thousand-seed weight.

C HiCKPeA (Cicer arietinum L.) is an annual self-pollinating member of the Fabaceae family. It is a diploid species $(2 n=$ $2 x=16$ ) with a genome size of about $740 \mathrm{mbp}$ (Varshney et al., 2013). In 2014 chickpea was cultivated over 14.8 million hectares that produced 14.2 million tons, making chickpea the second most important pulse crop globally (FAOSTAT, 2014). Of the total world chickpea production during 2014, $84.3 \%$ was produced in Asia, followed by 5.7\% in Oceania, 5.4\% in Africa, 3.4\% in America, and 1.2\% in Europe. Among the Asian countries, India (82.3\% of total Asian production) is the largest producer of chickpea, followed by Pakistan (6.3\%), Myanmar (4.1\%), and Turkey (3.8\%). Chickpea is classified into two botanical groups: desi (purple flower and small, dark, angular seeds) and kabuli (white flower and large, cream-colored seeds) types that are mainly grown in semiarid tropical and temperate regions of the world, respectively (Gangola et al., 2013; Gangola et al., 2016). The global annual production of desi chickpea is about four times that of kabuli type (Thudi et al., 2014).

Published in Crop Sci. 57:1594-1602 (2017).

doi: 10.2135/cropsci2016.08.0710

(C) Crop Science Society of America | 5585 Guilford Rd., Madison, WI 53711 USA All rights reserved. 
Chickpea seed is mainly composed of carbohydrates and proteins that contribute about $80 \%$ to total seed dry mass (Jukanti et al., 2012; Zia-Ul-Haq et al., 2007). Starch, a major storage carbon reserve, contributes two-thirds of chickpea seed weight (Gangola et al., 2014). Starch granules in chickpea seeds are composed of higher concentration of amylose (30 to 40\%) than starch in cereal grains ( $25 \%$ in wheat), which reduces the bioavailability of the starch and the calorie value of chickpea seeds (Jukanti et al., 2012). Chickpea seeds contain up to $28 \%$ protein on a dry weight basis, and the protein is rich in lysine but deficient in methionine amino acids. Therefore, chickpea seeds make an excellent dietary complement to cereals that are low in lysine but rich in methionine (Wood and Grusak, 2007). Protein concentration in chickpea seeds does not differ significantly from other pulse crops, including black gram, lentils, and red and white kidney bean (Jukanti et al., 2012), but shows higher in vitro digestibility (Chitra et al., 1995). Therefore, chickpea is an important component of food and feed in developing countries. However, higher concentration of raffinose family oligosaccharides (RFO) in chickpea seeds limits the adoption of chickpea as food or feed in developed countries (Gangola et al., 2013). Raffinose family oligosaccharides are sucrosyl-galactosides characterized by the presence of $\alpha(1 \rightarrow 6)$ linkage. Raffinose is the first member of the family, followed by stachyose and verbascose (Kannan et al., 2016). Raffinose family oligosaccharides play important physiological roles in plants, and in human diet at lower concentrations are considered as prebiotics. Raffinose family oligosaccharides escape digestion in the small intestine, but the microbes in the large intestine ferment RFO, producing short-chain fatty acids and small concentrations of deleterious gases (carbon dioxide, hydrogen, and methane) (Gangola et al., 2016). Consumption of chickpea seeds rich in RFO (2.0 to 7.6\%) increases the production of deleterious gases causing stomach discomfort, bloating, flatulence, and in extreme cases, diarrhea in humans (Gangola et al., 2013). Therefore, nutritional quality of chickpea seeds can be improved by increasing the concentrations of nutrients or reducing RFO concentration.

Chickpea breeding programs have mainly focused on increasing the yield by improving either valuable agronomic traits (Cho et al., 2002; Cobos et al., 2009) or resistance or tolerance to biotic and abiotic stresses (Patil et al., 2014; Sabbavarapu et al., 2013). Consequently, global chickpea yield has increased from $649 \mathrm{~kg} \mathrm{ha}^{-1}$ in 1965 to $967.6 \mathrm{~kg} \mathrm{ha}^{-1}$ in 2013 (FAOSTAT, 2013). However, breeding for nutritional quality improvement has rarely been attempted in chickpea (Gaur et al., 2007). The only seed-quality trait that has been extensively studied in chickpea is seed weight, as it is directly associated with yield. A major limitation to improving chickpea nutritional quality is the lack of extensive studies that analyzed
Table 1. Geographical origins and botanical types of chickpea genotypes used in the study.

\begin{tabular}{lrcc}
\hline \multicolumn{1}{c}{ Region } & Desi & Kabuli & Total \\
\hline South Asia & 68 & 18 & 86 \\
Southwest Asia & 13 & 11 & 24 \\
North Africa & 9 & 10 & 19 \\
Europe & 10 & 8 & 18 \\
Sub-Saharan Africa & 11 & 5 & 16 \\
Meso-America & 4 & 1 & 5 \\
South America & 0 & 2 & 2 \\
North America & 1 & 0 & 1 \\
\hline Total & 116 & 55 & 171 \\
\hline
\end{tabular}

seed-quality trait diversity in chickpea genotypes. Therefore, chickpea genetic resources that vary for seed-quality traits, which can be used in breeding programs to enhance chickpea nutritional quality, need to be identified. In a previous study (Gangola et al., 2013), natural variation for RFO concentrations was studied in a germplasm collection of 171 chickpea genotypes. A significant effect of genotype $(G)$, environment $(E)$, and their interaction $(G \times E)$ on RFO concentrations in chickpea seeds was observed. In the present study, the same germplasm collection was evaluated for variation in the selected seed-quality traits and their correlation to the seed RFO concentrations.

\section{MATERIALS AND METHODS Plant Material}

A collection of 171 chickpea genotypes was procured from International Crops Research Institute for the Semi-Arid Tropics (ICRISAT, Patancheru, India). The collection includes both desi and kabuli chickpea types collected from eight regions of the world (Table 1). All the chickpea accessions were grown in three different trials (Table 2): (i) field trial during 2008-2009 (F 2009), (ii) field trial during 2009-2010 (F 2010), and (iii) greenhouse trial during 2010 (G 2010). The seeds were harvested at maturity and used for analyses.

\section{Evaluation of Selected Seed-Quality Traits}

To calculate the thousand-seed weight (TSW), seeds were counted in three replications using an electronic seed counter (Seedburo Equipment Co.) and weighed using an electronic balance.

To determine the concentration of protein, total starch, and amylose, chickpea seeds were ground into a fine meal using a UDY cyclone mill (Udy Corporation) with a $0.5-\mathrm{mm}$ sieve. The seed meal was collected and stored at room temperature and used for analyses within $4 \mathrm{wk}$.

Total nitrogen was estimated in $250 \mathrm{mg}$ of seed meal by combustion method (FP-528 Crude protein/Nitrogen Analyser, Leco Corporation). The total nitrogen was multiplied by the nitrogen to protein conversion factor (6.25 for chickpea seeds) to obtain protein concentration (Karaca et al., 2011).

Total starch concentration in chickpea seed meal $(100 \pm 1$ $\mathrm{mg}$ ) was determined by stepwise enzymatic hydrolysis of starch into D-glucose molecules by a thermostable $\alpha$-amylase and amyloglucosidase enzymes using a commercial assay kit (Megazyme 
International Ireland Ltd.). The D-glucose molecules were incubated with glucose oxidase-peroxidase reagent that produced a red quinoneimine, whose absorbance was determined at $\mathrm{A}_{510} \mathrm{~nm}$ using a spectrophotometer (DU 800, Beckman Coulter Inc.). Total starch concentration was calculated as a percentage of chickpea seed meal on a fresh weight basis.

A modified method (Peng et al., 1999) including cesium chloride density gradient centrifugation (Asare et al., 2011) was followed to extract starch, which was used to determine amylose concentration using an iodine based method (Mahmood et al., 2007) with some modifications. In brief, purified starch $(5 \mathrm{mg})$ was sequentially suspended in $95 \%(\mathrm{v} / \mathrm{v})$ ethanol $(75$ $\mu \mathrm{L}), 1 \mathrm{M} \mathrm{NaOH}(450 \mu \mathrm{L})$, and deionized (18.2 $\mathrm{M} \Omega-\mathrm{cm})$ water (Nanopure-Diamond, Barnstead Thermolyne) with vigorous mixing using a vortex mixer (Mini Vortex, VWR International) and incubated at room temperature for $1 \mathrm{~h}$. An aliquot $(200 \mu \mathrm{L})$ was taken out and neutralized with $0.05 \mathrm{M}$ citric acid $(1 \mathrm{~mL})$, followed by addition of $800 \mu \mathrm{L}$ of $\mathrm{I}_{2}+\mathrm{KI}$ solution $(0.8$ $\mathrm{g}$ iodine $\left[\mathrm{I}_{2}\right]$ and $8 \mathrm{~g}$ potassium iodide $[\mathrm{KI}]$ in $1 \mathrm{~L}$ of deionized water). The solution was vigorously shaken using a vortex mixer, followed by adding deionized water to a final volume of $12 \mathrm{~mL}$. The absorbance was observed at dual wavelengths (535 and $620 \mathrm{~nm}$ ) and used to calculate amylose concentration (\%) in starch (Mahmood et al., 2007).

\section{Statistical Analysis}

The Shannon-Weaver diversity index (SDI), for pooled data of three environments, was calculated to determine diversity in each geographical region using the following formula (Gangola et al., 2013):

$$
\mathrm{SDI}=\frac{-\sum_{i=1}^{n} P_{i} \times \log _{e} P_{i}}{\log _{e} n}
$$

where $n$ represents the total number of phenotypic classes (frequency distribution classes of a particular phenotype) and $P_{i}$ is the proportion of total number of entries in the $i^{\text {th }}$ class. Phenotypic classes were prepared by using MINITAB 14 statistical software (Minitab Inc.). Box plot analysis was performed to represent the variation present in each growing environment. The assumptions of analysis of variance (ANOVA) were tested and met the requirements. Therefore, a general linear model was employed to calculate ANOVA in MINITAB 14, and the resulting mean sum of squares from ANOVA were used to calculate broad sense heritability $\left(H^{2}\right)$ as described (Singh et al., 1993). Correlation analysis was also performed using Minitab 14.

\section{RESULTS Diversity among Geographical Regions}

Desi and kabuli genotypes were classified into six groups each on the basis of their geographical origin. These groups also represented the major growing areas of chickpea production across the globe. The SDI was affected predominantly by variation in phenotype, followed by number of genotypes in each frequency distribution class. In desi types, the maximum SDI for all the selected seed-quality traits was observed in the South Asian genotypes (0.95, 
Table 3. Shannon-Weaver diversity index estimates for the germplasm collection.

\begin{tabular}{lcccc}
\hline $\begin{array}{c}\text { Geographical } \\
\text { regions }\end{array}$ & $\begin{array}{c}\text { Thousand- } \\
\text { seed } \\
\text { weight }\end{array}$ & Protein & $\begin{array}{c}\text { Total } \\
\text { starch }\end{array}$ & Amylose \\
\hline Desi genotypes & 0.76 & 0.45 & 0.59 & 0.64 \\
$\quad$ Europe & 0.63 & 0.41 & 0.56 & 0.24 \\
Meso-America & 0.45 & 0.45 & 0.61 & 0.59 \\
North Africa & 0.95 & 0.77 & 0.85 & 0.85 \\
South Asia & 0.47 & 0.52 & 0.68 & 0.66 \\
Southwest Asia & 0.58 & 0.49 & 0.67 & 0.61 \\
Sub-Saharan Africa & & & & \\
\hline Kabuli genotypes & 0.8 & 0.89 & 0.38 & 0.41 \\
$\quad$ Europe & 0.77 & 0.76 & 0.6 & 0.39 \\
North Africa & 0.36 & 0.36 & 0.36 & 0.19 \\
South America & 0.87 & 0.82 & 0.82 & 0.45 \\
South Asia & 0.68 & 0.7 & 0.69 & 0.35 \\
Southwest Asia & 0.29 & 0.29 & 0.53 & 0.15 \\
Sub-Saharan Africa & & & & \\
\hline
\end{tabular}

0.77, 0.85, and 0.85 for TSW, protein, total starch, and amylose, respectively). The Southwest Asian and European desi chickpea genotypes showed the second maximum SDI for protein, total starch, amylose $(0.52,0.68,0.66)$, and TSW (0.76), respectively. Similarly, in kabuli types, the South Asian genotypes had maximum SDI for TSW (0.87), total starch (0.82), and amylose (0.44); however, maximum SDI (0.89) for protein was observed in European genotypes. The European kabuli genotypes ( 0.80 and 0.41) showed second maximum SDI for TSW and amylose, whereas the South Asian and Southwest Asian kabuli genotypes showed the second maximum SDI for protein (0.82) and total starch (0.69), respectively (Table 3 ).

\section{Variation for Selected Seed-Quality Traits among Desi and Kabuli Genotypes}

Desi and kabuli genotypes grown in the greenhouse showed significantly $(P<0.05)$ higher average seed weight $(220.5$ and $276.5 \mathrm{~g})$ than those grown in field environments (186.8 and $255.5 \mathrm{~g}$ ). Kabuli genotypes ( 85.3 to 528.0 $\mathrm{g})$, on average, showed significantly $(P<0.05)$ higher TSW than desi types (89.0 to $380.0 \mathrm{~g}$ ) (Fig. 1a). In desi genotypes, TSW ranged from 89.0 to $312.0,110.0$ to 380.0 , and 113.0 to $362.6 \mathrm{~g}$, with a mean of $161.5,184.7$, and 220.5 g; whereas in kabuli genotypes, TSW varied between 97.0 and 528.0, 107.0 and 579.0, and 85.3 and $505.2 \mathrm{~g}$, with a mean of 245.0, 266.0, and $276.5 \mathrm{~g}$ during F 2009, F 2010, and G 2010, respectively. South Asian genotypes showed the maximum variation, 114.6 to 332.4 and 115.7 to 412.9 $\mathrm{g}$, for TSW among geographical regions followed by the European genotypes (128.8 to 278.2 and 191.1 to $394.9 \mathrm{~g}$ ) in both desi and kabuli genotypes, respectively.

Desi genotypes contained 15.1 to $27.8,17.1$ to 30.1 , and 15.3 to $25.3 \%$ of protein, with an average of 19.1 ,
23.8 , and $19.5 \%$, while it ranged from 6.2 to $23.2,18.2$ to 31.6 , and 14.8 to $24.7 \%$ among kabuli genotypes, with means of 19.3, 25.1, and 19.4\% during F 2009, F 2010, and G 2010, respectively (Fig. 1b). Protein concentration showed maximum variation (16.7 to 27.5 and 18.8 to 24.8\%) among the South Asian genotypes in both the desi and kabuli genotypes.

Total starch concentration ranged from 33.7 to 47.4 , 31.3 to 43.3 , and 28.7 to $47.1 \%$ among desi genotypes, with average values of $39.6,36.1$, and $40.4 \%$, whereas it varied from 36.5 to $53.8,33.0$ to 48.2 , and 34.0 to $50.5 \%$ in kabuli types, with mean values of $44.6,40.8$, and $43.3 \%$ during F 2009, F 2010, and G 2010, respectively (Fig. 1c). The South Asian genotypes (34.1 to 42.9 and 37.0 to $49.0 \%$ ) varied most widely for total starch concentration, followed by the Southwest Asian genotypes (35.3 to 40.6 and 37.2 to $46.3 \%)$ in desi and kabuli types, respectively. In desi genotypes, amylose constituted 26.8 to $38.3,30.0$ to 38.1 , and 29.1 to $35.4 \%$ of total starch, with mean values of 31.6, 34.3 , and $31.2 \%$, whereas in kabuli genotypes, total starch comprised 28.0 to $35.1,29.7$ to 37.8 , and 28.7 to $33.9 \%$ of amylose, with average values of $31.3,34.2$, and $31.5 \%$ during F 2009, F 2010, and G 2010, respectively (Fig. 1d).

\section{Impact of Genotype and Environment on Selected Seed-Quality Traits and Their Heritability}

Analysis of variance (Table 4), using a general linear model, established a significant $(P<0.001)$ effect of $\mathrm{G}$ and $\mathrm{E}$ on TSW and concentrations of protein, total starch, and amylose in both desi and kabuli chickpea types. The interaction between genotype and environment also influenced these traits significantly $(P<0.001)$. However, no significant difference was observed among biological replications.

In the chickpea germplasm collection, the highest broad sense heritability of 0.86 and 0.72 was observed for TSW, followed by total starch (0.32 and 0.51$)$, protein (0.37 and 0.17), and amylose (0.11 and 0.14) in desi and kabuli genotypes respectively (Table 4).

\section{Correlation Analysis among Selected Seed-Quality Traits and to Raffinose Family Oligosaccharides}

In desi genotypes, TSW was positively correlated with total starch $(r=0.67)$ but negatively with amylose $(r=$ $-0.30)$ and protein $(r=-0.57)$, significant at $P<0.01$. Total starch showed a significant $(P<0.01)$ negative correlation with amylose $(r=-0.26)$ and protein $(r=-0.54)$; however, in desi genotypes amylose and protein were positively correlated $(r=0.31$ ), significant at $P<0.01$ (Table 5). Kabuli genotypes showed a similar correlation among selected seed-quality traits as observed in desi types, except 

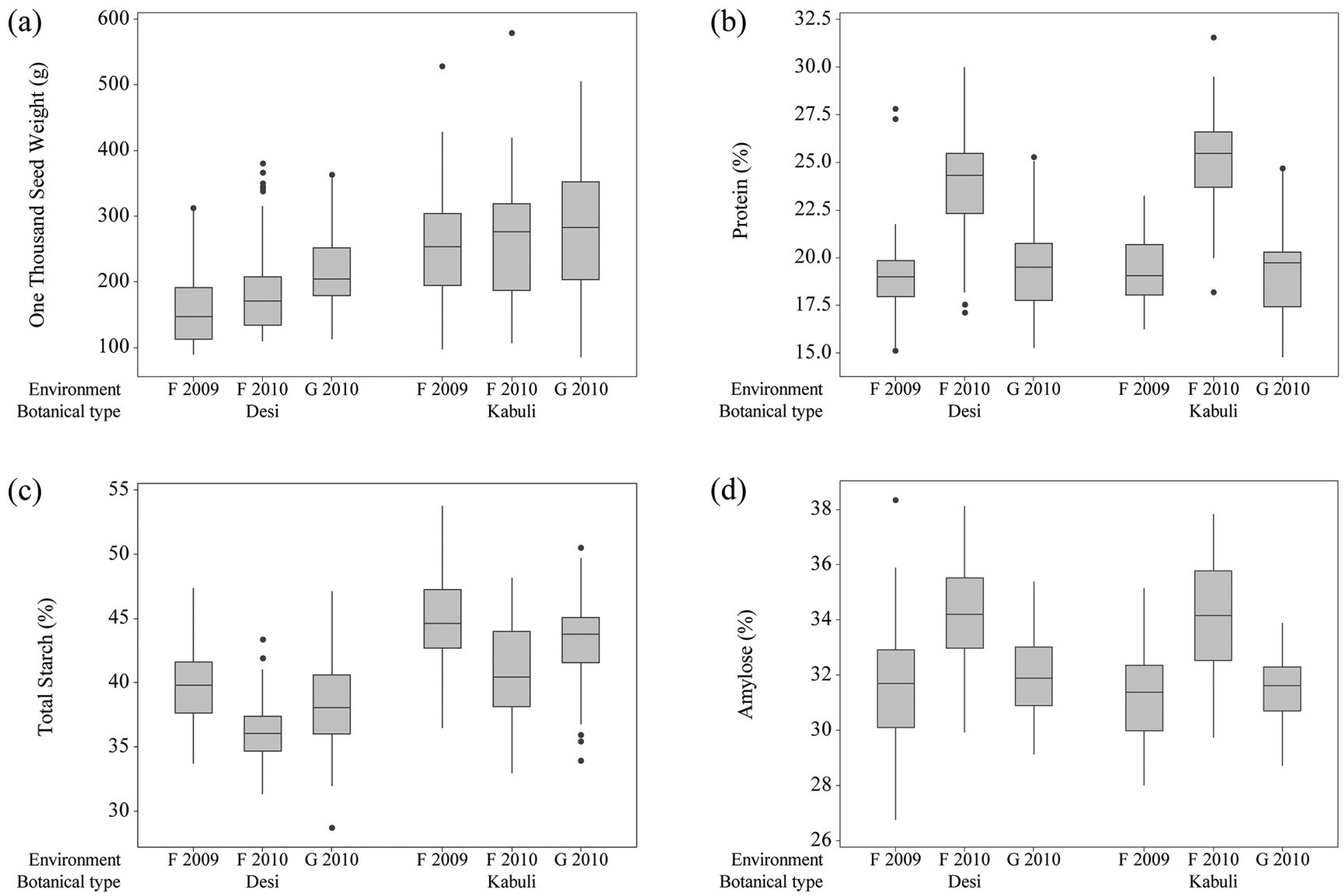

Fig. 1. Box plot analysis for: (a) one thousand seed weight (g), (b) protein (\%), (c) total starch (\%), and (d) amylose (\% of total starch) in desi and kabuli chickpea genotypes grown in different environments. F 2009 and F 2010 represent the field trials of $2008-2009$ and 2009-2010, respectively, whereas G 2010 represents the greenhouse trial in 2010. The upper and lower error bars show the nonoutlier range of the data set. The box symbolizes the interquartile range (IQR), whereas the middle line is the median value of the data set. The dark circles represent the outliers, calculated as the data points out of the 1.5 times the IQR.

Table 4. Analysis of variance (ANOVA) and broad-sense heritability $\left(H^{2}\right)$ for selected seed-quality traits in desi and kabuli chickpea genotypes. TSW, thousand-seed weight.

\begin{tabular}{|c|c|c|c|c|c|c|}
\hline \multirow{2}{*}{$\begin{array}{c}\text { Botanical } \\
\text { type }\end{array}$} & \multirow[b]{2}{*}{ Seed trait } & \multicolumn{4}{|c|}{ Mean sum of squares } & \multirow[b]{2}{*}{$H^{2}$} \\
\hline & & Genotype (G) & Environment $(\mathrm{E})$ & $G \times E$ & Replication & \\
\hline \multirow[t]{4}{*}{ Desi } & TSW & $1.9 \times 10^{4 \star \star \star}$ & $2.2 \times 10^{5 \star \star \star}$ & $6.7 \times 10^{2 \star \star \star}$ & $8.7 \times 10^{2} \mathrm{~ns} \dagger$ & 0.86 \\
\hline & Protein & $15.7^{\star \star \star}$ & $2.7 \times 10^{3 * * *}$ & $5.5^{\star \star \star}$ & $0.4 \mathrm{~ns}$ & 0.37 \\
\hline & Starch & $22.4^{\star \star \star}$ & $5.7 \times 10^{2 * \star *}$ & $8.7^{\star \star \star}$ & $2.4 n s$ & 0.32 \\
\hline & Amylose & $15.7^{\star \star \star}$ & $1.3 \times 10^{3 * * *}$ & $9.2^{* * \star}$ & 3.0ns & 0.11 \\
\hline \multirow[t]{4}{*}{ Kabuli } & TSW & $4.3 \times 10^{4 * \star *}$ & $2.7 \times 10^{4 * \star *}$ & $3.3 \times 10^{3 * * *}$ & $3.6 \times 10^{3} \mathrm{~ns}$ & 0.72 \\
\hline & Protein & $15.1^{\star \star \star}$ & $1.7 \times 10^{3 * \star *}$ & $9.1^{\star \star \star}$ & $0.2 \mathrm{~ns}$ & 0.17 \\
\hline & Starch & $40.6^{\star \star \star}$ & $2.9 \times 10^{2 * \star *}$ & $9.0^{\star \star \star}$ & $0.2 \mathrm{~ns}$ & 0.51 \\
\hline & Amylose & $24.0^{\star \star \star *}$ & $1.0 \times 10^{3 * \star *}$ & $13.7^{\star \star \star}$ & $6.9 \mathrm{~ns}$ & 0.14 \\
\hline \multirow[t]{4}{*}{ Overall } & TSW & $3.4 \times 10^{4 * \star *}$ & $2.2 \times 10^{5 * * *}$ & $1.6 \times 10^{3 * * *}$ & $2.3 \times 10^{3} \mathrm{~ns}$ & 0.81 \\
\hline & Protein & $15.1^{* \star \star}$ & $4.6 \times 10^{3 \star \star \star}$ & $6.8^{\star \star \star}$ & $0.5 \mathrm{~ns}$ & 0.29 \\
\hline & Starch & $35.4^{\star \star \star}$ & $8.8 \times 10^{2 \star \star \star}$ & $8.8^{\star \star \star}$ & $4.7 \mathrm{~ns}$ & 0.38 \\
\hline & Amylose & $15.8^{\star \star \star}$ & $3.3 \times 10^{3 * \star *}$ & $10.0^{\star \star \star}$ & $32.2 \mathrm{~ns}$ & 0.12 \\
\hline
\end{tabular}

***Significant at $P \leq 0.001$.

$\dagger \mathrm{ns}$, not significant.

for amylose, showing similar but insignificant correlation to TSW $(r=-0.04)$, total starch $(r=-0.03)$, and protein $(r=0.1)$ (Table 5). Correlation analysis with pooled data from desi and kabuli also exhibited similar correlations among selected seed-quality traits (Table 5). Total
RFO $(r=-0.24,-0.16 ; P<0.001,0.05)$, raffinose $(r=$ $-0.2,-0.18 ; P<0.001,0.05)$, and stachyose $(r=-0.3$, $-0.14 ; P<0.001,0.05)$ showed a significant negative correlation to TSW in desi and kabuli types, respectively, whereas verbascose $(r=0.17 ; P<0.05)$ had a significant 
Table 5. Correlations among the selected seed-quality traits in chickpea. TSW, thousand-seed weight.

\begin{tabular}{|c|c|c|c|c|c|c|c|c|c|}
\hline $\begin{array}{l}\text { Botanical } \\
\text { type }\end{array}$ & Genotype & $\begin{array}{l}\text { Seed } \\
\text { trait }\end{array}$ & Starch & Amylose & Protein & Raffinose & Stachyose† & Verbascose $†$ & $\begin{array}{l}\text { Total } \\
\text { RFO† }\end{array}$ \\
\hline \multirow[t]{4}{*}{ Desi } & 121 & TSW & $0.672^{\star \star}$ & $-0.304^{\star *}$ & $-0.568^{\star *}$ & $-0.196^{\star \star \star}$ & $-0.296^{\star \star \star}$ & $-0.082 n s$ & $-0.243^{\text {***}}$ \\
\hline & & Starch & & $-0.259^{\star \star}$ & $-0.543^{\star \star}$ & $0.049 n s$ & $0.055 n s$ & $0.117^{\star}$ & $0.053 \mathrm{~ns}$ \\
\hline & & Amylose & & & $0.310^{\star \star}$ & $0.018 n s$ & $0.018 n s$ & $0.088 n s$ & $0.026 n s$ \\
\hline & & Protein & & & & $-0.015 \mathrm{~ns}$ & $0.017 \mathrm{~ns}$ & $0.119^{*}$ & $-0.011 \mathrm{~ns}$ \\
\hline \multirow[t]{4}{*}{ Kabuli } & 56 & TSW & $0.678^{\star \star}$ & $-0.038 n s \neq$ & $-0.302^{\star}$ & $-0.184^{*}$ & $-0.136^{\star}$ & $0.169^{*}$ & $-0.161^{*}$ \\
\hline & & Starch & & $-0.029 n s$ & $-0.362^{\star \star}$ & $0.011 n s$ & $-0.013 n s$ & $0.179 n s$ & $-0.03 n s$ \\
\hline & & Amylose & & & $0.095 n s$ & $0.044 \mathrm{~ns}$ & 0.087ns & $0.102 n s$ & $0.077 \mathrm{~ns}$ \\
\hline & & Protein & & & & $0.156^{\star}$ & $0.14^{\star}$ & 0.118ns & $0.195^{\star}$ \\
\hline \multirow[t]{4}{*}{ Overall } & 171 & TSW & $0.538^{\star \star}$ & $-0.076 n s$ & $-0.133^{\star \star}$ & $-0.09^{*}$ & $-0.114^{*}$ & $0.123^{\star}$ & $-0.078^{*}$ \\
\hline & & Starch & & $-0.271^{\star \star}$ & $-0.403^{\star \star}$ & $0.131^{*}$ & $0.133^{*}$ & $0.143^{*}$ & $0.153^{*}$ \\
\hline & & Amylose & & & $0.480^{\star *}$ & $0.013 \mathrm{~ns}$ & $0.028 n s$ & $0.073 n s$ & $0.024 n s$ \\
\hline & & Protein & & & & $0.06 n s$ & $0.104^{\star}$ & $-0.021 n s$ & $0.081^{*}$ \\
\hline
\end{tabular}

*Significant at $P \leq 0.05$.

${ }^{* *}$ Significant at $P \leq 0.01$.

*** Significant at the $P \leq 0.001$.

† Data for raffinose, stachyose, verbascose, and total RFO (raffinose family oligosaccharides) concentrations were obtained from Gangola et al. (2013).

$\ddagger$ ns, not significant.

positive correlation to TSW in kabuli types but no correlation in desi types. Among RFO, only verbascose was positively correlated to starch in desi types, significant at $P<0.05$, but no correlation of RFO to starch was found in kabuli types. However, pooled data of desi and kabuli types showed a significant $(P<0.05)$ positive correlation of starch to raffinose $(r=0.131)$, stachyose $(r=0.13)$, verbascose $(r=0.24)$, and total RFO $(r=0.15)$. Protein was positively correlated to verbascose $(r=0.12)$ only in desi types, but to raffinose $(r=0.16)$, stachyose $(r=0.21)$, and total RFO $(r=0.2)$ in kabuli types, significant at $P<0.05$. No significant correlation was found among RFO and amylose in desi and kabuli types.

\section{DISCUSSION}

To improve selected seed-quality traits in chickpea and initiate breeding programs, identification of suitable plant genetic resources is essential (Cardi, 2016). A very few studies are available that analyze seed-quality traits other than seed weight in a large collection of chickpea genotypes. The germplasm collection used in the present study included genotypes from different geographical regions of the world corresponding to chickpea production areas (FAOSTAT, 2014). Thousand seed weight, total starch, protein, and amylose varied significantly among 171 chickpea genotypes grown in the three environments (Fig. 1), which makes the chickpea germplasm collection valuable for future studies to identify and characterize genomic regions associated with seed-quality traits using association or linkage mapping approaches. The higher TSW (grams) and total starch concentration (percentage) in kabuli genotypes $(229.2 \pm 46.8 \mathrm{~g}$ and 42.9 $\pm 1.9 \%)$ compared with desi types $(198.0 \pm 19.6 \mathrm{~g}$ and 38.0 $\pm 1.8 \%)$ concurred with the conclusions of Kujur et al. (2014) and Frimpong et al. (2009), respectively. However, average values for protein $(20.8 \pm 2.6$ and $21.3 \pm 3.3 \%)$ and amylose ( $32.4 \pm 1.7$ and $32.2 \pm 1.7 \%$ of total starch) concentrations did not show significant difference between desi and kabuli genotypes, respectively, which was also in agreement with previous results (Frimpong et al., 2009). Phenotypic variation also coincided with SDI values for different geographical regions. The SDI for some regions was not shown, as they included very few genotypes that were not adequate to calculate SDI. South Asian genotypes had the maximum representation in the collection ( $>50 \%$ genotypes of the collection), therefore showing the maximum variation or SDI for selected seed-quality traits. The eight kabuli genotypes of European origin had maximum variation for seed protein content (17 to 24\%), therefore showing the highest SDI for the trait.

The conclusions of the present study were based on the trials in three different environments. Therefore, distinct environments may not follow the same effect or correlations among seed-quality traits studied. Significant effect of G, E, and their interaction on seed composition suggested a multienvironment-based approach for chickpea seed-quality improvement programs. These results were in agreement with the conclusions of previous studies on chickpea (Frimpong et al., 2009; Gangola et al., 2012; Gangola et al., 2013), lentil (Lens culinaris, Tahir et al., 2011), soybean (Glycine max, Kumar et al., 2010), and barley (Hordeum vulgare L., Cory et al., 2017). Biosynthesis of starch, amylose, and protein is complex in plants and includes a number of genes or enzymes that have been shown to be affected by environment, thus affecting the accumulation of the final product (Dupont and Altenbach, 2003; Thitisaksakul et al., 2012). Chickpea seed weight is one of the extensively studied traits, as it is directly associated with yield. In earlier studies, seed weight has been shown to be influenced by $G, E$, and $G \times E$ in chickpea and other legumes (Frimpong et al., 2009; Tahir 
et al., 2011). The low to medium broad sense heritability $\left(H^{2}\right)$ of intrinsic seed-quality traits (total starch, protein, and amylose) and high $H^{2}$ of extrinsic trait TSW suggested the higher environmental sensitivity of the former. Seed weight is also a quantitative trait, and it was significantly affected by $\mathrm{G}, \mathrm{E}$, and $\mathrm{G} \times \mathrm{E}$ but showed very high $H^{2}$. This could be explained by noncrossover $\mathrm{G} \times \mathrm{E}$ interaction for TSW trait (Kang, 2002), that is, no significant change in genotype ranking in diverse environments resulting in high $\mathrm{H}^{2}$. However, other selected seed-quality traits showed a crossover $\mathrm{G} \times \mathrm{E}$ interaction (Supplemental Fig. S1). High heritability for seed weight concurred with the conclusions of Tuba Biçer and Sakar (2008) and Pushpavalli et al. (2015). Optimum growth conditions support higher seed weight and enhanced accumulation of starch in seed (Famerra et al., 2015). Consequently, higher average TSW and total starch concentration was observed in G 2010 than in F 2009 and F 2010. However, a rainy environment has been shown to increase $\alpha$-amylase activity, reducing starch accumulation (Famerra et al., 2015). Therefore, chickpea genotypes grown in F 2010 (93.6 $\mathrm{mm}$ precipitation) showed reduced starch accumulation in seeds compared with those grown in $\mathrm{F}$ 2009 (26.6 $\mathrm{mm}$ precipitation). Being negatively correlated to starch, protein, and amylose showed higher concentrations in F 2010-grown genotypes compared with the genotypes grown during F 2009 and G 2010.

Starch and protein are main constituents of chickpea seeds, whereas amylose, together with amylopectin, constitutes the starch granule. Starch and protein biosynthesis depend on the carbon to nitrogen ratio $(\mathrm{C}: \mathrm{N})$ and have shown positive and negative correlations with $\mathrm{C}: \mathrm{N}$, respectively (Truong et al., 2013). Therefore, a negative correlation between starch and protein concentrations was observed in the present study. The positive correlation between starch concentration and seed weight was similar to that reported in lentil (Tahir et al., 2011). Starch biosynthesis favors amylopectin accumulation, as it is essential for the starch granule structure (Zeeman et al., 2010); thus it showed a negative correlation with amylose in the present study. Being negatively correlated to starch, protein, and amylose showed a positive correlation in chickpea genotypes. Raffinose family oligosaccharides biosynthesis can be triggered by different abiotic stresses; therefore, higher RFO accumulation was observed in chickpea seeds grown in field conditions than those grown in optimal greenhouse conditions (Gangola et al., 2013). Stress conditions reduce the seed development process, thus allowing less accumulation of metabolites and resulting in reduced seed weight. Consequently, a significant negative correlation was found among RFO and TSW, which was the most consistent correlation of RFO to seed-quality traits analyzed in the present study (Table 5). Although RFO showed significant positive correlation to starch and protein, it was not consistent in desi and kabuli genotypes.
Table 6. Desi and kabuli chickpea genotypes with higher values for selected seed quality traits.

\begin{tabular}{lccc}
\hline \multicolumn{1}{c}{ Trait } & Genotype & $\begin{array}{c}\text { Botanical } \\
\text { type }\end{array}$ & $\begin{array}{c}\text { Value for } \\
\text { phenotype }\end{array}$ \\
\hline Thousand-seed & ICC 4958 & Desi & $342.6 \pm 34.5$ \\
weight & ICCV 07108 & Desi & $330.8 \pm 34.5$ \\
(g) & ICCV 94916-4 & Desi & $325.4 \pm 24.5$ \\
& ICCV 94916-8 & Desi & $316.1 \pm 24.4$ \\
& ICCV 98902 & Desi & $332.4 \pm 31.3$ \\
& ICC 16774 & Kabuli & $394.9 \pm 30.2$ \\
& ICC 17109 & Kabuli & $537.4 \pm 37.8$ \\
& ICCV 07313 & Kabuli & $412.9 \pm 19.4$ \\
\hline Protein & ICC 5912 & Desi & $27.1 \pm 1.9$ \\
concentration & ICC 8397 & Desi & $27.5 \pm 2.4$ \\
(\%) & ICC 4861 & Kabuli & $23.1 \pm 3.5$ \\
& ICC 5116 & Kabuli & $24.3 \pm 6.3$ \\
& ICC 5270 & Kabuli & $24.8 \pm 4.1$ \\
\hline Total starch & ICCV 93954 & Desi & $43.5 \pm 0.4$ \\
concentration & ICCV 98901 & Desi & $41.6 \pm 1.0$ \\
(\%) & ICCV 98904 & Desi & $41.6 \pm 1.1$ \\
& ICCV 06302 & Kabuli & $47.0 \pm 1.5$ \\
& ICCV 07313 & Kabuli & $46.4 \pm 0.5$ \\
& ICCV 91302 & Kabuli & $49.0 \pm 1.3$ \\
\hline Amylose & ICC 14456 & Desi & $34.4 \pm 0.8$ \\
concentration & ICC 14497 & Desi & $34.4 \pm 1.4$ \\
(\% of total starch) & ICC 14592 & Desi & $34.2 \pm 0.2$ \\
& ICC 7292 & Kabuli & $34.9 \pm 1.7$ \\
& ICC 8273 & Kabuli & $34.6 \pm 2.4$ \\
\hline
\end{tabular}

Desi and kabuli chickpea genotypes with consistent performance in different environments were identified for selected seed-quality traits separately (Table 6). The other contrasting genotypes have also been highlighted in Supplementary Table S1. The two genotypes ICC 4958 (desi type) and ICC 17109 (kabuli type) exhibited a balanced proportion of protein (18.7 \pm 1.5 and $20.7 \pm 0.3 \%$ ), total starch (42.4 \pm 7.3 and $46.1 \pm 4.1 \%)$, and amylose $(32.8 \pm 3.0$ and $31.4 \pm 1.4 \%$ of total starch), with TSW (317.3 \pm 16.6 and $537.4 \pm 37.8 \mathrm{~g})$ toward the higher end, respectively. Total RFO concentrations were $3.8 \pm 0.5$ and $4.3 \pm 0.7 \mathrm{mmol} 100$ $\mathrm{g}^{-1}$ of chickpea seed meal for ICC 4958 and ICC 17109, respectively, which are approximately equivalent to medians of total RFO variation in the germplasm collection.

To identify new genetic resources for chickpea seedquality traits, the present study evaluated a germplasm collection of 171 chickpea genotypes for phenotypic variation in multienvironment trials. A significant effect of $G$, $\mathrm{E}$, and their interaction on selected seed-quality traits was established. Thousand seed weight influences the yield, an important consideration in all crop improvement programs. The information on correlation among the selected seedquality traits with TSW can be used to make direct and indirect selections during chickpea breeding programs. The selected chickpea genotypes (Table 6) can be used to develop new chickpea varieties with improved seed-quality traits, enhancing its nutritional and economical value. 


\section{Acknowledgments}

This work was financially supported by Canada Research Chairs Program and Agriculture and Agri-Food Canada Internationalization program. The core research grant of International Crops Research Institute for Semi-Arid Tropics (ICRISAT, Patancheru, India) is acknowledged for providing the germplasm collection, two replicated trials over two years, and seeds from the respective harvests that were used for analyses in this study. Runfeng Wang is a grateful holder of a Ph.D. fellowship from the China Scholarship Council.

\section{Conflict of Interest Disclosure}

The authors declare there to be no conflict of interest.

\section{References}

Asare, E.K., S. Jaiswal, J. Maley, M. Båga, R. Sammynaiken, B.G. Rossnagel, and R.N. Chibbar. 2011. Barley grain constituents, starch composition, and structure affect starch in vitro enzymatic hydrolysis. J. Agric. Food Chem. 59:4743-4754. doi:10.1021/ jf200054e

Cardi, T. 2016. Cisgenesis and genome editing: Combining concepts and efforts for a smarter use of genetic resources in crop breeding. Plant Breed. 135:139-147. doi:10.1111/pbr.12345

Chitra, U., V. Vimala, U. Singh, and P. Geervani. 1995. Variability in phytic acid content and protein digestibility of grain legumes. Plant Foods Hum. Nutr. 47:163-172. doi:10.1007/BF01089266

Cho, S.H., J. Kumar, J.L. Shultz, K. Anupama, F. Tefera, and F.J. Muehlbauer. 2002. Mapping genes for double podding and other morphological traits in chickpea. Euphytica 128:285-292. doi:10.1023/A:1020872009306

Cobos, M.J., P. Winter, M. Kharrat, J.I. Cubero, J. Gil, T. Millan, and J. Rubio. 2009. Genetic analysis of agronomic traits in a wide cross of chickpea. Field Crops Res. 111:130-136. doi:10.1016/j. fcr.2008.11.006

Cory, A.T., M.P. Gangola, A. Anyia, M. Båga, and R.N. Chibbar. 2017. Genotype, environment and $\mathrm{G} \times \mathrm{E}$ interaction influence $(1,3 ; 1,4)-\beta$-d-glucan fine structure in barley (Hordeum vulgare L.). J. Sci. Food Agric. 97:743-752. doi:10.1002/jsfa.7789

Dupont, F.M., and S.B. Altenbach. 2003. Molecular and biochemical impacts of environmental factors on wheat grain development and protein synthesis. J. Cereal Sci. 38:133-146. doi:10.1016/ S0733-5210(03)00030-4

Faměra, O., M. Mayerová, I. Burešová, L. Kouřimská, and M. Prášilová. 2015. Influence of selected factors on the content and properties of starch in the grain of non-food wheat. Plant Soil Environ. 61:241-246. doi:10.17221/13/2015-PSE

FAOSTAT. 2014. FAOSTAT database. http://faostat3.fao.org/ download/Q/QC/E (accessed 21 Dec. 2015).

FAOSTAT. 2013. FAOSTAT database. http://faostat.fao.org/ site/567/default.aspx\#an cor (accessed 8 Apr. 2016).

Frimpong, A., A. Sinha, B. Tar'an, T.D. Warkentin, B.D. Gossen, and R.N. Chibbar. 2009. Genotype and growing environment influence chickpea (Cicer arietinum L.) seed composition. J. Sci. Food Agric. 89:2052-2063. doi:10.1002/jsfa.3690

Gangola, M.P., M. Båga, P.M. Gaur, and R.N. Chibbar. 2014. Chickpea-Nutritional quality and role in alleviation of global malnourishment. Legume Perspectives 3:33-35.
Gangola, M.P., S. Jaiswal, U. Kannan, P.M. Gaur, M. Båga, and R.N. Chibbar. 2016. Galactinol synthase enzyme activity influences raffinose family oligosaccharides (RFO) accumulation in developing chickpea (Cicer arietinum L.) seeds. Phytochemistry 125:88-98. doi:10.1016/j.phytochem.2016.02.009

Gangola, M.P., Y.P. Khedikar, P.M. Gaur, M. Båga, and R.N. Chibbar. 2013. Genotype and growing environment interaction shows a positive correlation between substrates of raffinose family oligosaccharides (RFO) biosynthesis and their accumulation in chickpea (Cicer arietinum L.) seeds. J. Agric. Food Chem. 61:4943-4952. doi:10.1021/jf3054033

Gangola, M.P., Y.P. Khedikar, P.M. Gaur, M. Båga, R. Varshney, and R.N. Chibbar. 2012. Variation in important seed constituents among various chickpea genotypes. Qual. Assur. Saf. Crop. 4:136-158.

Gaur, P.M., C.L.L. Gowda, E.J. Knights, T. Warkentin, N. Acikgoz, S.S. Yadav, and J. Kumar. 2007. Breeding achievements. In: S.S. Yadav, R.J. Redden, W. Chen, and B. Sharma, editors, Chickpea breeding and management. Cromwell Press, Trowbridge, UK. p. 391-416.

Jukanti, A.K., P.M. Gaur, C.L.L. Gowda, and R.N. Chibbar. 2012. Nutritional quality and health benefits of chickpea (Cicer arietinum L.): A review. Br. J. Nutr. 108:S11-S26. doi:10.1017/ S0007114512000797

Kang, M.S. 2002. Genotype-environment interaction: Progress and prospects. In: M.S. Kang, editor, Quantitative genetics, genomics and plant breeding. CAB International, Wallingford, UK. p. 221-243.

Kannan, U., R. Sharma, Y. Khedikar, M.P. Gangola, S. Ganeshan, M. Båga, and R.N. Chibbar. 2016. Differential expression of two galactinol synthase isoforms LcGolS1 and LcGolS2 in developing lentil (Lens culinaris Medik. cv CDC Redberry) seeds. Plant Physiol. Biochem. 108:422-433. doi:10.1016/j.plaphy.2016.08.004

Karaca, A.C., N. Low, and M. Nickerson. 2011. Emulsifying properties of chickpea, faba bean, lentil and pea proteins produced by isoelectric precipitation and salt extraction. Food Res. Int. 44:2742-2750. doi:10.1016/j.foodres.2011.06.012

Kujur, A., D. Bajaj, M.S. Saxena, S. Tripathi, H.D. Upadhyaya, C.L.L. Gowda, S. Singh, A.K. Tyagi, M. Jain, and S.K. Parida. 2014. An efficient and cost-effective approach for genic microsatellite marker-based large-scale trait association mapping: Identification of candidate genes for seed weight in chickpea. Mol. Breed. 34:241-265. doi:10.1007/s11032-014-0033-3

Kumar, V., A. Rani, L. Goyal, A.K. Dixit, J.G. Manjaya, J. Dev, and M. Swamy. 2010. Sucrose and raffinose family oligosaccharides (RFOs) in soybean seeds as influenced by genotype and growing location. J. Agric. Food Chem. 58:5081-5085. doi:10.1021/ jf903141s

Mahmood, T., M.A. Turner, and F.L. Stoddard. 2007. Comparison of methods for colorimetric amylose determination in cereal grains. Starch 59:357-365. doi:10.1002/star.200700612

Patil, B.S., R.L. Ravikumar, J.S. Bhat, and C.D. Soregaon. 2014. Molecular mapping of QTLs for resistance to early and late Fusarium wilt in chickpea. Czech J. Genet. Plant. 50:171-176.

Peng, M., M. Gao, E.-S.M. Abdel-Aal, P. Hucl, and R.N. Chibbar. 1999. Separation and characterization of A- and B-type starch granules in wheat endosperm. Cereal Chem. 76:375-379. doi:10.1094/CCHEM.1999.76.3.375 
Pushpavalli, R., L. Krishnamurthy, M. Thudi, P.M. Gaur, M.V. Rao, K.H. Siddique, T.D. Colmer, N.C. Turner, R.K. Varshney, and V. Vadez. 2015. Two key genomic regions harbour QTLs for salinity tolerance in ICCV $2 \mathrm{c} \times \mathrm{cJG} 11$ derived chickpea (Cicer arietinum L.) recombinant inbred lines. BMC Plant Biol. 15:124. doi:10.1186/s12870-015-0491-8

Sabbavarapu, M.M., M. Sharma, S.K. Chamarthi, N. Swapna, A. Rathore, M. Thudi, P.M. Gaur, S. Pande, S. Singh, L. Kaur, and R.K. Varshney. 2013. Molecular mapping of QTLs for resistance to Fusarium wilt (race 1) and Ascochyta blight in chickpea (Cicer arietinum L.). Euphytica 193:121-133. doi:10.1007/ s10681-013-0959-2

Singh, M., S. Ceccarelli, and J. Hamblin. 1993. Estimation of heritability from varietal trials data. Theor. Appl. Genet. 86:437-441. doi:10.1007/BF00838558

Tahir, M., N. Lindeboom, M. Båga, A. Vandenberg, and R.N. Chibbar. 2011. Composition and correlation between major seed constituents in selected lentil (Lens culinaris Medik) genotypes. Can. J. Plant Sci. 91:825-835. doi:10.4141/cjps2011-010

Thitisaksakul, M., R.C. Jiménez, M.C. Arias, and D.M. Beckles. 2012. Effects of environmental factors on cereal starch biosynthesis and composition. J. Cereal Sci. 56:67-80. doi:10.1016/j. jcs.2012.04.002

Thudi, M., H.D. Upadhyaya, A. Rathore, P.M. Gaur, L. Krishnamurthy, M. Roorkiwal, S.N. Nayak, S.K. Chaturvedi, P.S. Basu, N.V. Gangarao, A. Fikre, P. Kimurto, P.C. Sharma, M.S. Sheshashayee, S. Tobita, J. Kashiwagi, O. Ito, A. Killian, and R.K. Varshney. 2014. Genetic dissection of drought and heat tolerance in chickpea through genome-wide and candidate genebased association mapping approaches. PLoS One 9:e96758. doi:10.1371/journal.pone.0096758
Truong, Q., K. Koch, J.M. Yoon, J.D. Everard, and J.V. Shanks. 2013. Influence of carbon to nitrogen ratios on soybean somatic embryo (cv. Jack) growth and composition. J. Exp. Bot. 64:29852995. doi:10.1093/jxb/ert138

Tuba Biçer, B.T., and D. Sakar. 2008. Heritability and gene effects for yield and yield components in chickpea. Hereditas 145:220224. doi:10.1111/j.1601-5223.2008.02061.x

Varshney, R.K., C. Song, R.K. Saxena, S. Azam, S. Yu, A.G. Sharpe, S. Cannon, J. Baek, B.D. Rosen, B. Tar'an, T. Millan, X.D. Zhang, L.D. Ramsay, A. Iwata, Y. Wang, W. Nelson, A.D. Farmer, P.M. Gaur, C. Soderlund, R.V. Penmetsa, C.Y. Xu, A.K. Bharti, W.M. He, P. Winter, S.C. Zhao, J.K. Hane, N. Carrasquilla-Garcia, J.A. Condie, H.D. Upadhyaya, M.C. Luo, M. Thudi, C.L.L. Gowda, N.P. Singh, J. Lichtenzveig, K.K. Gali, J. Rubio, N. Nadarajan, J. Dolezel, K.C. Bansal, X. Xu, D. Edwards, G.Y. Zhang, G. Kahl, J. Gil, K.B. Singh, S.K. Datta, S.A. Jackson, J. Wang, and D.R. Cook. 2013. Draft genome sequence of chickpea (Cicer arietinum) provides a resource for trait improvement. Nat. Biotechnol. 31:240-246. doi:10.1038/nbt.2491

Wood, J.A., and M.A. Grusak. 2007. Nutritional value of chickpea. In: S.S. Yadav, R.J. Redden, W. Chen, and B. Sharma, editors, Chickpea breeding and management. Cromwell Press, Trowbridge, UK. p. 101-142.

Zeeman, S.C., J. Kossmann, and A.M. Smith. 2010. Starch: Its metabolism, evolution, and biotechnological modification in plants. Annu. Rev. Plant Biol. 61:209-234. doi:10.1146/annurevarplant-042809-112301

Zia-Ul-Haq, M., S. Iqbal, S. Ahmad, M. Imran, A. Niaz, and M.I. Bhanger. 2007. Nutritional and compositional study of desi chickpea (Cicer arietinum L.) cultivars grown in Punjab, Pakistan. Food Chem. 105:1357-1363. doi:10.1016/j.foodchem.2007.05.004 